\title{
Пространственная структура распределения степных и лесных районов Донецкой области
}

\author{
А. А. Блакберн $ه$, В. М. Остапко, А. Л. Золотой \\ Государственное учреждение "Донеиякий ботанический сад», Украина \\ (83059, г. Донеик, пр. Ильича, 110)
}

\begin{abstract}
Аннотация: Цель исследования - оценка пространственной структуры экологического каркаса ряда административно-территориальных подразделений (АТП) центральной и восточной части Донецкой области как единого полигона.

Материальl и методы. Определялись количество и площади двух основных типов природных (квазиприродных) экосистем региона - степных и лесопокрытых территорий в границах трех районов - Шахтерского, Амвросиевского, Старобешевского и Донецко-Макеевской агломерации. Путем расчленения полигона исследования на квадраты $7 \times 7$ км оценивались диаграммы рассеяния квадратов по соотношению в них площадей степных и лесопокрытых территорий, количественное распределение квадратов по диапазону занимаемых природных площадей, характер их географического распределения и концентрации.

Результаты и обсуждение. Показано, что по характеру распределения квадратов по соотношению в них площадей степных и лесопокрытых территорий во всех АТП, кроме города Донецка, преобладает степной компонент. Лесной компонент существенен также для Амвросиевского и особенно для Шахтерского районов, что приближает их к лесостепному характеру ландшафта. В Старобешевском районе лесной компонент практически отсутствует, а степной представлен вытянутыми участками, приуроченными к долинам местной речной сети. Географическое распределение квадратов по данным характеристикам показывает наибольшую концентрацию природных территорий (степных, лесопокрытых экосистем и их совокупности) в Шахтерском и Амвросиевском районах и наименьшую - в Старобешевском.

Заключение. Рекомендуется участки повышенной концентрации природных территорий Шахтерского и Амвросиевского районов считать кластерами природных ядер регионального значения формируемой экологической сети региона. Степные участки речных долин Старобешевского района признать экологическими коридорами местного и субрегионального уровня. Природные и квазиприродные ареалы городов Донецка и Макеевки - природными ядрами и коридорами местного или субрегионального уровня в зависимости от их значимости в общей системе экологической сети.
\end{abstract}

Ключевые слова: экологический каркас, экологическая сеть, пространственная структура территории, административно-территориальные подразделения Донецкой области.

Для цитирования: Блакберн А.А., Остапко В.М., Золотой А. Л. Пространственная структура распределения степных и лесных районов Донецкой области // Вестник Воронежского государственного университета. Серия: География. Геоэкология, 2021, № 2, с. 20-29. DOI: https://doi.org/10.17308/geo.2021.2/3443

\section{ВВЕДЕНИЕ}

С позиции оптимизации экологического каркаса регионального или субрегионального уровня очень важно знать не только количественные характеристики составляющих его природных и квазиприродных экосистем, но и характер их взаимного размещения в едином пространстве. Это позволяет выявить участки территории с высокой, средней и низкой их концентрацией и в результате получить многоуровневую иерархическую пространственную структуру экологического каркаса всего исследуемого региона или значительной его части с перспективой оформления в соответствующую экологическую сеть.

В ряде своих публикаций мы уже рассматривали пространственную структуру расположения природных и природно-антропогенных (квазиприродных) участков (экосистем) в рамках от-

(C) Блакберн А. А., Остапко В. М., Золотой А. Л., 2021

$\varangle$ Блакберн Андрей Альфредович, e-mail: blackburn.fox@mail.ru

(c) (i) Контент доступен под лицензией Creative Commons Attribution 4.0 License. 
дельных административных районов Донецкой области $[1,2,3,4,5]$.

Сравнительный количественный анализ пространственной структуры степных и лесопокрытых участков на территории субрегионального уровня - трех административных районов и двух городов показал очень неоднородную картину их количественного распределения, обусловленную, на наш взгляд, характером хозяйственной деятельности, а также общей структурой рельефа. Нами были выявлены особенности количественного распределения степных и лесных участков в рамках каждого административно-территориального подразделения (АТП) и проведен их сравнительный анализ по показателям фрагментированности обоих типов природных экосистем.

В настоящем сообщении рассматривается пространственная структура распределения степных и лесных участков в границах этих же АТП, но уже как единого целого полигона. Данный аспект позволяет выявить и количественно оценить экологический каркас территории субрегионального (надрайонного) уровня и определить общий географический характер его пространственной структуры.

Цель данной работы - провести оценку пространственной структуры экологического каркаса
АТП центральной и восточной части Донецкой области как единого полигона.

Исходя из цели, были поставлены следующие задачи: 1) выявить общий характер пространственного размещения и концентрации степных и лесопокрытых участков в каждом АТП и на всем полигоне; 2) оценить количественное распределение квадратов концентрации этих двух типов природных экосистем по диапазонам занимаемых площадей; 3) получить общую пространственно-географическую характеристику всей территории и на основе этого выявить наиболее приоритетные участки с точки зрения формирования экологической сети региона.

\section{МАТЕРИАЛЫ И МЕТОДЫ}

Исследования распространялись на два наиболее распространенных в регионе типа растительного покрова - степного и лесного $[1,3]$ в границах Шахтерского, Амвросиевского, Старобешевского административных районов и двух городов - Донецка и Макеевки.

Данные АТП занимают всю восточную и центральную части Донецкой области и представляют основные типы ландшафтов центрального Донбасса - Донецкий кряж и прилегающие к нему части Приазовской возвышенности и Приазовской низменности (рис. 1).
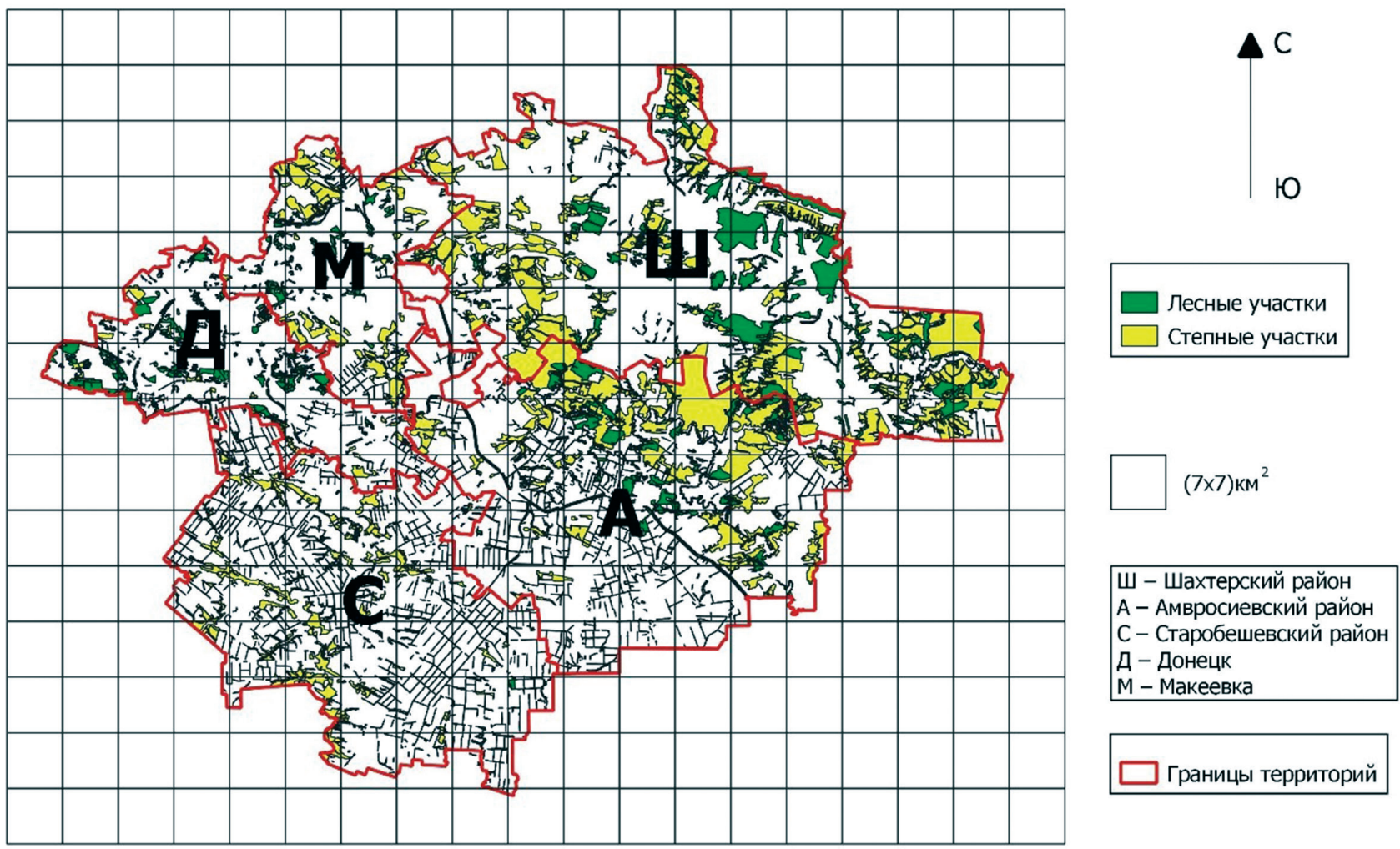

Puc.1. Картосхема пространственной структуры степных и лесопокрытых участков в административно-территориальных подразделениях Донецкой области

[Fig.1. Schematic map of the spatial structure of steppe and forest-covered sites in the administrative-territorial divisions of the Donetsk region]

Вестник ВГУ, Серия: География. Геоэкология, 2021, № 2, 20-29 
Шахтерский район расположен на южном и юго-западом макросклонах Донецкого кряжа - главного геоморфологического образования региона, имеющего сложную, преимущественно холмисто-грядовую структуру рельефа. В структуре природной растительности Шахтерского района преобладают типичные (разнотравно-типчаково-ковыльные) и петрофитные степи, а также байрачные (овражные) леса, плотность которых здесь одна из самых высоких в Донбассе. Из-за сложности рельефа в Шахтерском районе относительно невелика площадь распаханных земель, но, напротив, одна из самых высоких степеней урбанизации. На его территории располагаются четыре города с населением свыше 70 тыс. человек в каждом, а также множество поселков городского типа.

Амвросиевский район граничит с юга с Шахтерским и имеет более сглаженную структуру рельефа - холмисто-грядовую только на севере, на границе с Шахтерским районом, и преимущественно равнинную на остальной части. Хозяйственная структура Амвросиевского района в основном аграрная, степень урбанизации незначительная.

Города Донецк и Макеевка находятся в центре Донецкой области и образуют единую агломерацию, расположенную к западу от Шахтерского и Амвросиевского районов. Несмотря на преобладание здесь городских застроек, в пределах административных границ обоих городов высока доля лесопокрытых участков, а также сельскохозяйственных угодий. Последние преобладают на северных, восточных и юго-восточных окраинах Макеевки.

С позиции физико-географического районирования Шахтерский, Амвросиевский районы и Донецко-Макеевская агломерация находятся в Донецкой возвышенной ландшафтной области Донецкой северо-степной провинции [6].

Старобешевский район граничит на севере с Донецком и на северо-востоке и востоке с Амвросиевским районом. На всей его территории абсолютно преобладает аграрный тип ландшафтов. Степень урбанизации очень низкая. Согласно физико-географическому районированию Старобешевский район практически полностью находится в Левобережно-Днепровско-Приазовской северо-степной провинции в Приазовской возвышенной области и только юго-восточная его часть расположена в Приазовской низменной области [6].

В качестве степных экосистем нами изучались участки с естественной, преимущественно травянистой растительностью, как природного так природно-антропогенного происхождения без дальнейшей их дифференциации.

Под лесными экосистемами рассматривались все лесопокрытые участки (либо с существенным преобладанием лесной растительности) как природного (байрачные и пойменные леса), так и полуприродного и искусственного происхождения - лесопосадки всех типов, от посаженных и восстановленных лесов, до лесозащитных полос различного назначения.

Для определения этих типов экосистем был применён метод их выделения и оконтуривания на космоснимках Sentinel-2A, визуально определяемых по цвету и текстуре изображения как степные или лесные с последующим анализом пространственной структуры с помощью компьютерной программы QGIS 3.4.1.

Оценка пространственной структуры взаимного расположения степных и лесных участков проводилась на основе группировки квадратов $(7 \times 7$ км) с различным соотношением площадей степных и лесопокрытых территорий. Используя метод ординации $[7,8]$, были определены количественные характеристики распределения квадратов по соотношению в них степных и лесопокрытых комплексов.

\section{РЕЗУЛЬТАТЫ И ОБСУЖДЕНИЕ}

На рисунке 1 показано расположение степных и лесных участков на исследованных АТП.

Их количество, общая и средняя площади (в га), относительная доля (в \% к площади АТП) приведены в таблице.

Как видно из таблицы, практически во всех АТП площади степных участков существенно превышают лесные территории, хотя число последних в несколько раз больше, чем степных. Исключением здесь является Донецко-Макеевская агломерация, где суммарная лесопокрытая площадь превышает степную, а их число на порядок больше, чем степных участков.

Соответственно и средняя площадь степных участков в несколько раз превышает лесные (а в Шахтерском и особенно в Амвросиевском районах средняя площадь степных участков на порядок больше, чем лесных).

В целом во всех АТП как едином полигоне суммарная площадь степей в полтора раза превышает лесопокрытые участки, что свидетельствует о преимущественно степном характере ландшафта в регионе, даже не смотря на огромное количество искусственных лесопосадок и лесополос. 
Количество, общая и средняя площадь природных территорий в АТП

[Table. Number, total and average area of natural territories in ATD]

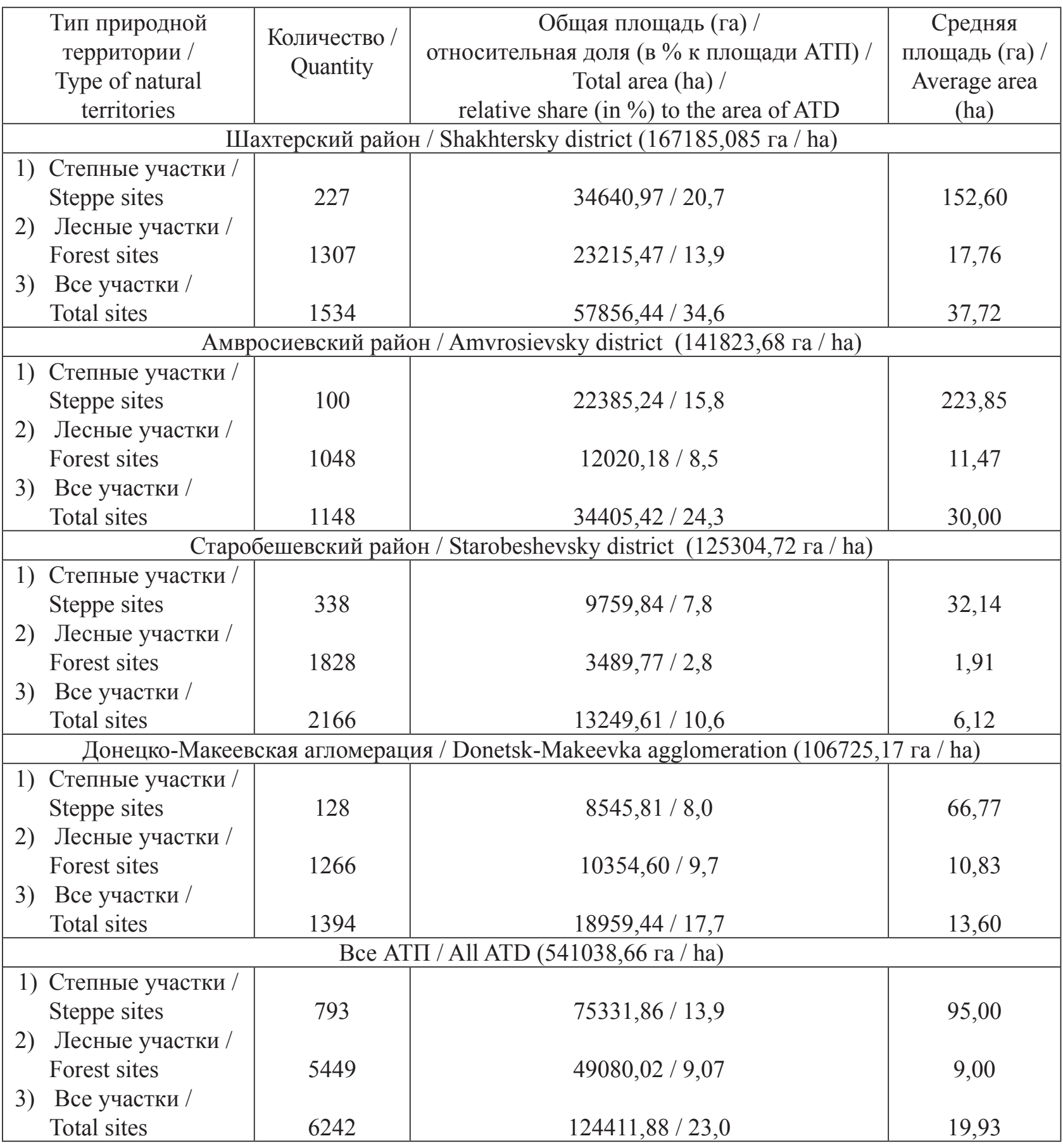

Общая площадь степных и лесопокрытых участков на исследованном полигоне равна 124411,9 га, что составляет $23 \%$ от всей его площади. Фактически это и есть основа экологического каркаса изученного региона. Средний размер степных участков на порядок превышает лесопокрытые комплексы, а средняя их площадь равна 19,93 га. На фоне их огромного числа - 6242, это свидетельствует о крайне высокой степени фрагментации природных и квазиприродных экосистем региона.

С точки зрения оценки экологического каркаса всей исследуемой территории, важно знать характер пространственного распределения природных и квазиприродных комплексов как в отдельных АТП, так и по всему полигону, чтобы выявить участки повышенной концентрации, что дает возможность разработать пути оптими- 
зации экологического каркаса региона в соответствующую ему экологическую сеть.

С этой целью для каждого АТП были построены диаграммы рассеяния значений квадратов по соотношению в них площадей степных и лесопокрытых участков, которые представлены на рисунке 2. Такая интерпретация пространственной структуры АТП показывает не только соотношение площадей степных и лесных участков в

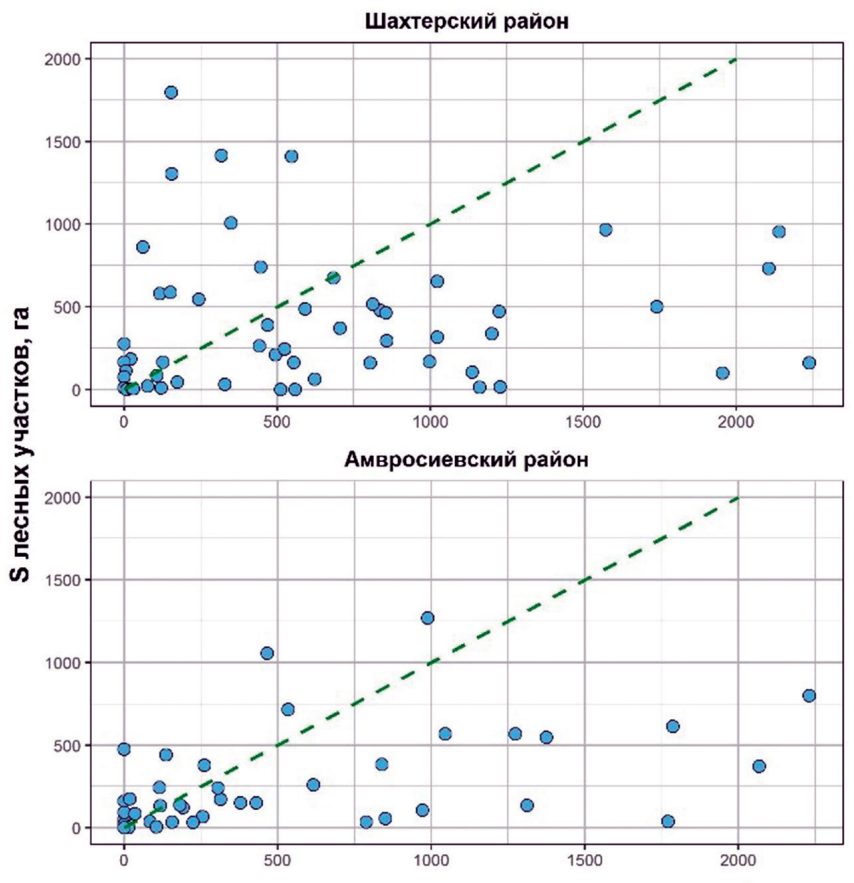

$\mathrm{S}$ степных участков, га каждом конкретном квадрате, но и частоты этих соотношений в соответствии с размерным классом выделенных участков. В итоге можно получить целостную картину количественного распределения квадратов по наличию в них площадей рассматриваемых экосистем и выяснить характер преобладания квадратов с тем или иным типом распределения площадей природных территорий.
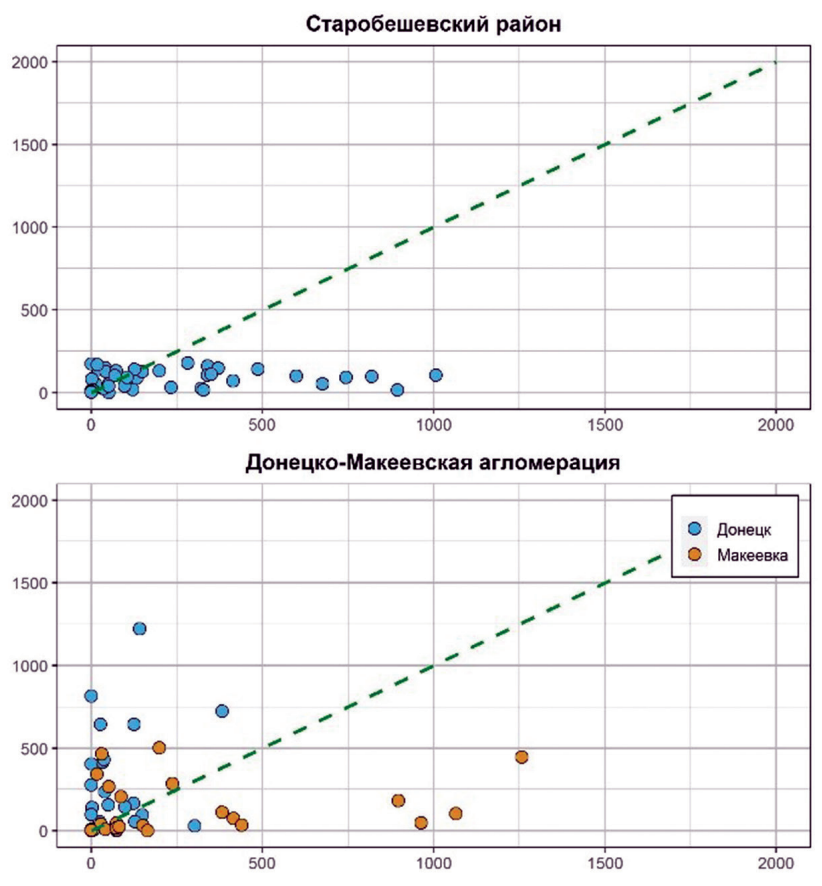

Puc. 2. Диаграммы рассеяния значений квадратов по площадям степных и лесопокрытых участков АТП

[Fig. 2. Scatter diagrams of the values of the squares over the areas of steppe and forest-covered sites of the ATD]

Так, например, диаграмма рассеивания квадратов в Шахтерском районе показывает общее преобладание квадратов с преимущественным содержанием степных территорий, среди которых имеются квадраты, имеющие суммы степных площадей, превышающие 2000 га. Встречаются также и квадраты с преобладанием лесопокрытых территорий, но их гораздо меньше и с более скромным соотношением такого преобладания (менее 2000 га). Абсолютное же большинство квадратов в Шахтерском районе лежит в диапазоне степных площадей (500-1250 га), лесных (1-700 га). Вторая по количеству группа квадратов района находится в примерно равном соотношении степных и лесопокрытых площадей, но в самом нижнем размерном диапазоне (1-200 га). Все это вместе говорит о преобладании в структуре ландшафта Шахтерского района степного характера растительности, но при относительно высокой доле лесного комплекса.
В Амвросиевском районе имеет место еще большее преобладание степной растительности над лесной. Тут также существуют квадраты с общей площадью степных территорий, превышающей 2000 га. Доля лесопокрытых квадратов с существенным преобладанием существенно меньше, чем в Шахтерском районе. В целом в Амвросиевском районе большинство квадратов имеют примерно равные соотношения степных и лесопокрытых территорий в наименьшем размерном классе - 1-500 га.

Совершенно иная картина распределения квадратов по соотношению степных и лесопокрытых площадей в Старобешевском районе. Здесь имеет место абсолютное преобладание степных площадей над лесными. Примечательно, что практически нет квадратов, где сумма степных участков превышала бы 1000 га. Доля же лесопокрытых площадей в районе ничтожно мала. Ни в одном квадрате она не превышает и 200 га. Это свиде- 
тельствует о том, что Старобешевский район практически безлесен. Почти все его лесопокрытые участки являются полезащитными и придорожными лесополосами. Степных площадей в районе также намного меньше, чем в Шахтерском и Амвросиевском районах (более, чем в три и два раза соответственно). Все это говорит о том, что в целом Старобешевский район крайне беден природными территориями.

Очень интересна картина рассеивания квадратов в Донецко-Макеевской агломерации. Если в Макеевке характер рассеивания квадратов по площадям природных территорий близок к административным районам - преобладание квадратов с преимущественно степными площадями, то в Донецке явно преобладают лесопокрытые квадраты и практически полное отсутствие квадратов с

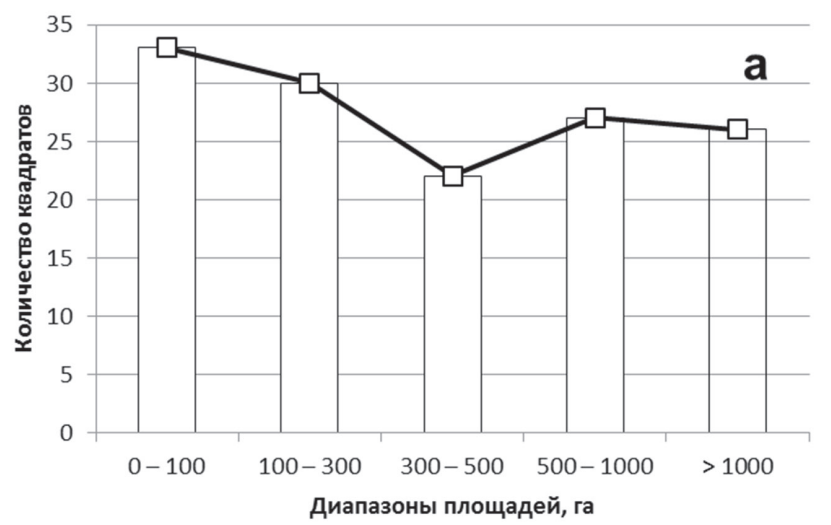

крупными и даже средними степными комплексами. Данный факт объясняется довольно просто - в административных границах Макеевки, особенно на северной, восточной и южной ее периферии, существенная доля аграрных ландшафтов и, соответственно, связанных с ними квазиприродных территорий. Напротив, в Донецке велика роль искусственных лесонасаждений - парков, скверов, рекреационных зон. Роль остепненных участков (главным образом, городских пустырей и залежей) очень незначительна.

Общий характер распределения квадратов по занимаемым площадям степных и лесопокрытых территорий и их совокупности по всему полигону рассматриваемых АТП показан на рисунке 3 в виде диаграмм их распределения по диапазонам площадей (в га).

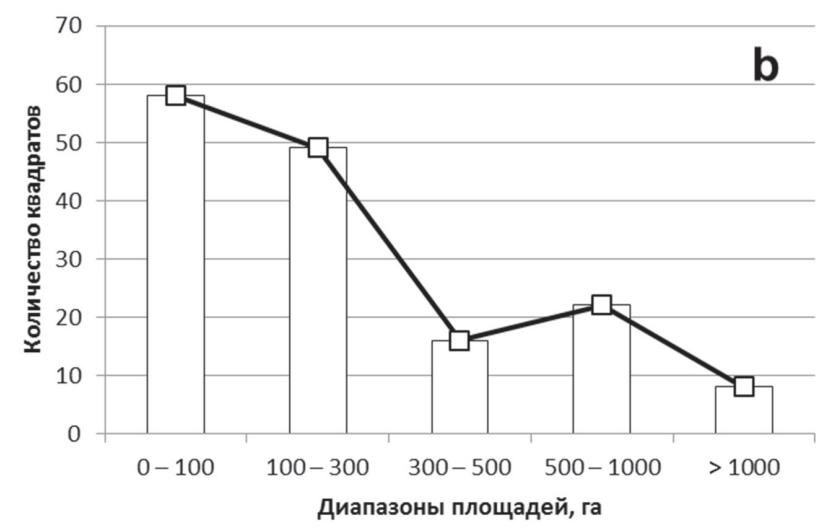

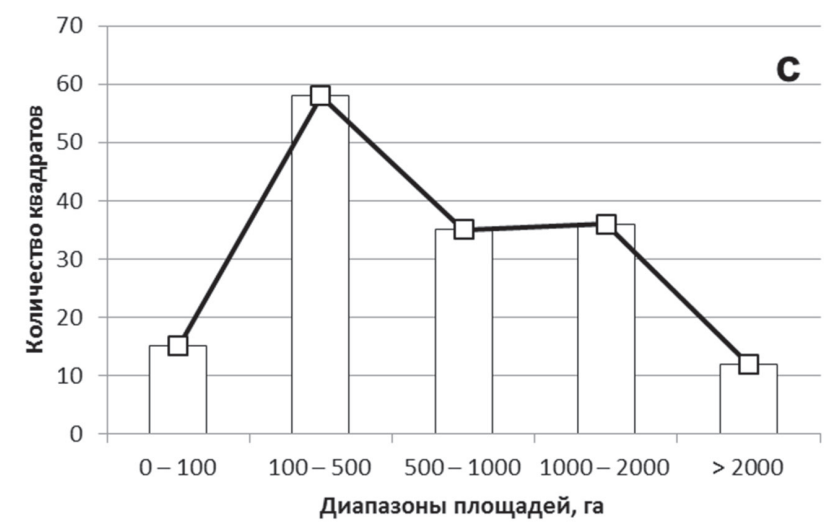

Puc. 3. Распределение квадратов по диапазонам занимаемых площадей: а - степных территорий; b - лесопокрытых территорий; c - совокупности степных и лесопокрытых территорий

[Fig. 3. Distribution of squares in the ranges of occupied areas: a - steppe territories; $\mathrm{b}$ - forest-covered territories; $\mathrm{c}$ - totality of steppe and forest-covered territories]

Как по площадям степных, так и по площадям лесопокрытых участков наибольшее число квадратов приходится на два самых нижних размерных класса - 0-100 га (максимум по обоим типам природных участков) и 100-300 га. Затем количество квадратов в следующем размерном класce (300-500 га) как по степным, так и по лесопо- крытым территориям резко падает, а затем опять возрастает - у степей в двух следующих размерных классах (500-1000 га и > 1000 га), а у лесопокрытых участков только в диапазоне 500-1000 га и опять снижается в самом крупном размерном классе (> 1000 га), где количество квадратов минимально. 
Таким образом, наименьшее число квадратов по площадям степных экосистем приходится на средний размерный класс - 300-500 га, а по площадям лесопокрытых территорий на самый крупный размерный класс - более 1000 га.

По совокупности обоих типов экосистем суммы площадей степных и лесопокрытых территорий картина распределения квадратов по диапазонам площадей выглядит следующим образом (рис. 3): наименьшее число квадратов приходится на два крайних диапазона площадей - 0-100 га и более 2000 га (минимум), а наибольшее на второй размерный класс - 100-500 га. Очевидно, что для всего полигона по обоим типам природных экосистем в большинстве случаев их суммарная площадь в среднем не превышает $10 \%$ от площади квадрата (49 км²). Это говорит в целом о низком уровне «мощности» экологического каркаса в данной части региона.

Географическая картина распределения квадратов по их насыщению степными и лесопокрытыми площадями в каждом АТП и по всему рассматриваемому полигону показана на рисунке 4 .
Видно, что по насыщенности степными территориями среди всех АТП выделяются Шахтерский и Амвросиевский районы, особенно западная, южная и восточная части Шахтерского района и, соответственно, северная (приграничная с Шахтерским) и восточная части Амвросиевского.

Также имеются насыщенные степями участки на северной, восточной и южной периферии города Макеевки и на отдельных участках Старобешевского района. В последнем степные территории приурочены к долине реки Кальмиус и ее притокам, где они имеют линейный характер (рис.1).

Лесопокрытые квадраты с их повышенной концентрацией также располагаются в центральной, восточной и северо-восточной частях Шахтерского района и на севере и центральной части Амвросиевского. Довольно сильно насыщен лесопокрытыми территориями город Донецк, особенно его западные, южные и восточные части. Напротив, крайне беден лесопокрытыми территориями весь Старобешевский район, а также западные и центральные части Шахтерского и запад, юго-запад Амвросиевского районов.
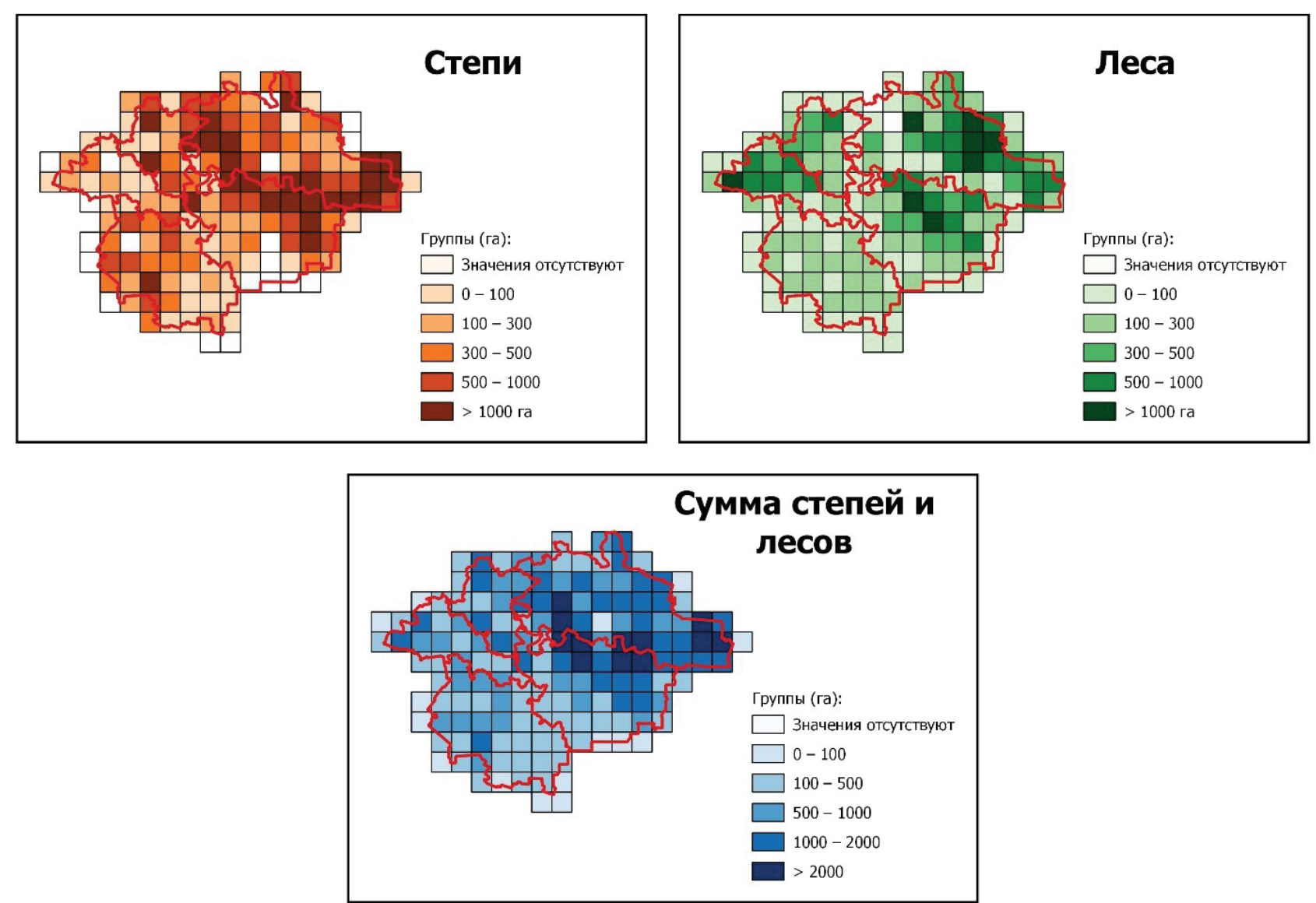

Puc. 4. Картосхема географического распределения квадратов по концентрации в них природных территорий

[Fig. 4. Schematic map of the geographical distribution of squares according to the concentration of natural sites in them] 
По совокупности степных и лесопокрытых территорий наибольшее количество насыщенных ими квадратов находится в Шахтерском и Амвросиевском районах. В Шахтерском - это преимущественно западные, южные и восточные его части, в Амвросиевском - северные (квадраты, общие с югом Шахтерского района) и центральные. Довольно насыщены этими территориями южная и северная периферия Макеевки и западная часть Донецка. В Старобешевском районе квадраты с относительно высокой концентрацией природных территорий идентичны таковым по степным участкам и, как говорилось выше, приурочены к реке Кальмиус и ее притокам.

\section{ЗАКЛЮЧЕНИЕ}

Оценка пространственной структуры экологического каркаса исследованных АТП посредством разбиения всего занимаемого ими полигона на квадраты и последующая дифференциация по занимаемым площадям природных участков - степных и лесопокрытых экосистем показала очень неоднородную картину их распределения в пространстве.

Диаграммы рассеяния значений квадратов по соотношению в них степных и лесопокрытых территорий показали, что при преобладании в целом степного характера ландшафта на всем полигоне исследованных АТП, в пространственной структуре Шахтерского и Амвросиевского районов существенен лесной компонент. Особенно это характерно для Шахтерского района, где пространственная структура природных территорий приближается к лесостепному ландшафту с преобладанием степного компонента. В Амвросиевском районе лесной компонент выражен в меньшей степени.

Напротив, в Старобешевском районе лесной компонент практически полностью отсутствует, последний представлен в абсолютном большинстве полезащитными и придорожными лесопосадками. Степной же компонент в районе в основном приурочен к долинам рек и представляет собой участки линейной конфигурации, наложенные на речную сеть района.

В Донецко-Макеевской агломерации, не смотря на географическую близость двух городов, картина пространственного распределения природных территорий сильно различается. Если в Макеевке распределение степных и лесопокрытых территорий по сути близко с Шахтерским и Амвросиевским районами, то в Донецке эта картина прямо противоположная. Площадь лесопокрытых участков в несколько раз превышает степные. Данный факт объясняется тем, что в административных границах Макеевки су- щественную ее часть занимают агроландшафты, особенно на северной, восточной и южной периферии. В административных границах Донецка агроландшафтов практически нет, напротив, велика доля лесопокрытых территорий так называемой «зеленой зоны» - городских лесопосадок, парков, скверов.

Количественное распределение квадратов по площадям, находящихся в них природных и квазиприродных территорий, показало их существенное преобладание в самых малых размерных классах для лесопокрытых территорий и незначительное преобладание для степных. По совокупности этих природных территорий меньше всего квадратов в самом малом (0-100 га) и самом крупном размерном классе (> 2000 га). Большая часть квадратов по совокупности природных территорий находится во втором по возрастанию размерном классе - 100-500 га.

Географический характер пространственного распределения квадратов показывает, что по обоим типам природных территорий наибольшую плотность их насыщения имеют Шахтерский и Амвросиевский районы, особенно восточная и западная части первого и северная и центральные части второго. Наименее насыщен природными территориями Старобешевский район.

Характер насыщения природными территориями Макеевки приближает ее к первым двум районам, но в обедненном виде. Донецк в этом плане стоит особняком: из-за своего сильного лесного компонента. Он разительно отличается от всех районов и Макеевки и представляет собой типичный ландшафт крупного города.

$\mathrm{C}$ точки зрения оптимизации экологического каркаса исследованных АТП в соответствующую экологическую сеть следует рекомендовать все выявленные участки наибольшей концентрации природных территорий Шахтерского и Амвросиевского районов и особенно на их общей границе объединить в общий кластер природных ядер будущей экологической сети регионального значения.

Степные участки Старобешевского района следует считать экологическими коридорами местного и/или субрегионального уровня, связывающие природные территории вышеназванных районов с более южными частями региона.

Природные участки Донецко-Макеевской агломерации могут считаться природными ядрами или коридорами местного и/или субрегионального уровня, в зависимости от значимости конкретных территорий и их расположения в общей структуре исследованного пространства. 


\section{СПИСОК ЛИТЕРАТУРЫ}

1. Блакберн А.А, Золотой А.Л. Количественная оценка состава природных территорий (степных и лесных участков) Шахтерского района Донецкой Народной Республики // Научные ведомости Белгородского государственного университета. Серия: Естественные науки, 2019, вып. 43, №3, с. 276-285. DOI: 10.18413/20754671-2019-43-3-276-285.

2. Блакберн А. А., Золотой А. Л. Пространственная структура степных и лесопокрытых участков в Шахтерском районе Донецкой Народной Республики // Peгиональные геосистемы, 2020, т. 44, №1, с. 85-96. DOI: 10.18413/2712-7443-2020-44-1-85-96.

3. Блакберн А. А., Остапко В. М., Золотой А. Л. Количественное распределение степных и лесных участков в Амвросиевском районе (Донецкая Народная Республика) // Журнал «Промылиленная ботаника», 2019, вып. 19, №4, с. 32-37.

4. Блакберн А.А., Золотой А.Л. Сравнительная оценка пространственной структуры лесных и степных экосистем Шахтерского и Амвросиевского районов ДНР // Биологическое разнообразие и устойчивость лесных и урбоэкосистем. Первые международнье чтения памяти Г.Ф. Морозова, 2019, с. 17-20.
5. Блакберн А.А., Остапко В.М., Золотой А.Л. Количественный анализ стуктуры лесных и степных участков Донецкой области // Вестник ВГУ. Серия: География. Геоэкология, 2021, №1, с. 25-36. DOI: https:// doi.org/10.17308/geo.2021.1/3253.

6. Маринич О.М, Шищенко П.Г. Фізична географія України: Підручник / Київ: Т-во «Знання», KOO, 2006. $511 \mathrm{c.}$

7. Шитиков В. К., Зинченко Т. Д. Многомерный статистический анализ экологических сообществ (обзор) // Теоретические проблемы экологии, 2019, № 1, с. 5-11. DOI: 10.25750/1995-4301-2019-1-005-011.

8. Jongman R., Braak C., Tongeren O. Data Analysis in Community and Landscape Ecology. Cambridge, Cambridge University Press., 1995. 299 p. DOI: 10.1017/ CBO9780511525575.

Конфликт интересов: Авторы декларируют отсутствие явных и потенциальных конфликтов интересов, связанных с публикацией настоящей статьи.

Поступила в редакцию 07.04.2020 Принята к публикации 28.05.2021

\title{
Spatial Structure of the Distribution of Steppe and Forest Areas of the Donetsk region
}

\author{
A.A. Blackburn ${ }^{\square}$, V.M. Ostapko, A. L. Zolotoi \\ State Institution Donetsk Botanical Garden, Ukraine \\ (110, Ilyich Ave., Donetsk, 83059)
}

\begin{abstract}
The purpose of the study is to assess the spatial structure of the ecological framework of a number of administrative-territorial divisions (ATD) of the central and eastern parts of the Donetsk region as a single polygon.

Objects and methods: the number and areas of two main types of natural (quasi-natural) ecosystems of the region were determined - steppe and forest-covered territories within the boundaries of three districts (Shakhtersky, Amvrosievsky, Starobeshevsky) and Donetsk-Makeyevka agglomeration. By dividing the entire study polygon into squares $\left(7 \times 7 \mathrm{~km}^{2}\right)$, the scattering diagrams of the squares were estimated according to the ratio of the areas of steppe and forested sites in them, the quantitative distribution of squares over the range of occupied areas of natural sites, the nature of their geographical distribution and concentration over the polygon.

Results. It was shown that according to the nature of the distribution of squares according to the ratio of the areas of steppe and forested territories in all ATD, except for the city of Donetsk, the steppe component prevails. The "forest" component is also significant for the Amvrosievsky and especially for the Shakhtersky districts, which brings them closer to the forest-steppe nature of the landscape. In the Starobeshevsky district, the "forest" component is practically absent, and the steppe component is represented by elongated sites confined to the valleys of the local river network. The geographical distribution of squares according to these characteristics shows the highest concentration of natural sites (steppe, forest-covered ecosystems and their totality) in the Shakhtersky and Amvrosievsky districts and the smallest in the Starobeshevsky district.
\end{abstract}

(C) Blackburn A. A., Ostapko V. M., Zolotoi A. L., 2021

$\triangle$ Andrei A. Blackburn, e-mail: blackburn.fox@mail.ru

The content is available under Creative Commons Attribution 4.0 License. 
Conclusions. It is recommended that the sites of increased concentration of natural territories of the Shakhtersky and Amvrosievsky districts be considered as clusters of natural cores of regional significance of the formed ecological network of the region, the steppe sections of the river system valleys of the Starobeshevsky district are recognized as ecological corridors of the local and subregional level. Natural and quasi-natural sites of the cities of Donetsk and Makeyevka are natural cores and corridors of the local or sub-regional level, depending on their importance in the overall system of the ecological network.

Key words: ecological framework, ecological network, spatial structure of the area, administrative-territorial divisions of the Donetsk region.

For citation: Blackburn A.A., Ostapko V.M., Zolotoi A. L. Spatial Structure of the Distribution of Steppe and Forest Areas of the Donetsk Region. Vestnik Voronezskogo gosudarstvennogo universiteta. Seria: Geografia. Geoekologia, 2021, no. 2, pp. 20-29. (In Russ.) DOI: https://doi.org/10.17308/geo.2021.2/3443

\section{REFERENCES}

1. Blakbern A.A, Zolotoy A. L. Kolichestvennaya otsenka sostava prirodnykh territoriy (stepnykh i lesnykh uchastkov) Shakhterskogo rayona Donetskoy Narodnoy Respubliki [Quantitative Estimation of the Composition of Natural Territories (Steppe and Forest Sites) of the Shakhtersk District of Donetsk People's Republic]. Nauchnye vedomosti Belgorodskogo gosudarstvennogo universiteta. Seriya: Estestvennye nauki, 2019, issue 43, no. 3, pp. 276-285. DOI: 10.18413/2075-4671-2019-43-3-276-285. (In Russ.)

2. Blakbern A.A., Zolotoy A.L. Prostranstvennaya struktura stepnykh i lesopopokrytykh uchastkov v Shakhterskom rayone Donetskoy Narodnoy Respubliki [Spatial structure of steppe and forest-covered areas in the Shakhtersk district of the Donetsk People's Republic]. Regional'nye geosistemy, 2020, vol. 44, no. 1, pp. 85-96. DOI: 10.18413/2712-7443-2020-44-1-85-96. (In Russ.)

3. Blakbern A.A., Ostapko V.M., Zolotoy A.L. Kolichestvennoe raspredelenie stepnykh i lesnykh uchastkov v Amvrosievskom rayone (Donetskaya Narodnaya Respublika) [Quantitative distribution of steppe and forest areas in the Amvrosievka district (Donetsk People's Republic)]. Promyshlennaya botanika, 2019, issue 19, no. 4, pp. 32-37. (In Russ.)

4. Blakbern A.A., Zolotoy A.L. Sravnitel'naya otsenka prostranstvennoy struktury lesnykh i stepnykh ekosistem Shakhterskogo i Amvrosievskogo rayonov DNR [Comparative assessment of the spatial structure of forest and steppe ecosystems of the Shakhtersky and Amvrosiyevky districts

\section{Блакберн Андрей Альфредович}

кандидат биологических наук, доцент, старший научный сотрудник отдела природной флоры и заповедного дела Донецкого ботанического сада, г. Донецк, Украина, ORCID: 0000-0003-1105-1877, e-mail: blackburn. fox@mail.ru

Остапко Владимир Михайлович

доктор биологических наук, профессор, заведующий отделом природной флоры и заповедного дела Донецкого ботанического сада, г. Донецк, Украина, e-mail: ostapko.dbs@mail.ru

Золотой Андрей Леонидович

аспирант отдела природной флоры и заповедного дела Донецкого ботанического сада, г. Донецк, Украина, e-mail: andreyzolotoy08@mail.ru of the DPR]. Biologicheskoe raznoobrazie i ustoychivost' lesnykh i urboekosistem. Pervye mezhdunarodnye chteniya pamyati G.F. Morozova, 2019, pp. 17-20. (In Russ.)

5. Blackburn A.A., Ostapko V. M., Zolotoi A. L. Quantitative Analysis of the Structure of Forest and Steppe Areas in the Donetsk Region. Vestnik Voronezskogo gosudarstvennogo universiteta. Seria: Geografia. Geoekologia, 2021, no. 1, pp. 25-36. DOI: https://doi.org/10.17308/ geo.2021.1/3253. (In Russ.)

6. Marinich O.M, Shishchenko P.G. Fizichna geografiya Ukraïni: Pidruchnik [Physical Geography of Ukraine: textbook]. Kiïv: T-vo «Znannya», KOO, 2006. 511 p. (In Ukr.)

7. Shitikov V.K., Zinchenko T.D. Mnogomernyy statisticheskiy analiz ekologicheskikh soobshchestv (obzor) [Multivariate statistical analysis of ecological communities (review)]. Teoreticheskie problemy ekologii, 2019, no. 1, pp. 5-11. DOI: 10.25750/1995-4301-2019-1-005-011. (In Russ.)

8. Jongman R., Braak, C., Tongeren O. Data Analysis in Community and Landscape Ecology. Cambridge, Cambridge University Press., 1995. 299 p. DOI: 10.1017/ CBO9780511525575.

Conflict of interests: The authors declare no information of obvious and potential conflicts of interest related to the publication of this article.

Received: 07.04.2020

Accepted: 28.05.2021

Andrei A. Blackburn

Cand. Sci. (Biol.), Associate Professor, Senior Researcher of the Department of Natural Flora and Conservation of the Donetsk Botanical Garden, Donetsk, Ukraine, ORCID: 0000-0003-1105-1877, e-mail: blackburn.fox@mail.ru

Vladimir M. Ostapko

Dr. Sci. (Biol.), Professor, Head of the Department of Natural Flora and Conservation of the Donetsk Botanical Garden, Donetsk, Ukraine, e-mail: ostapko.dbs@mail.ru

Andrei L. Zolotoi

Post-graduate student of the Department of Natural Flora and Conservation of the Donetsk Botanical Garden, Donetsk, Ukraine, e-mail: andreyzolotoy08@mail.ru 